\title{
中国東北地区ハルビン市近郊の 農村集落における北方系居住文 化に関する調査
}

INVESTIGATION INTO THE NORTHERN DWELLING CULTURE OF VILLAGES NEAR HARUBIN, CHINA

$\begin{array}{ll}\text { 月舘敏栄 —* }-1 & \text { 野口孝博 }-* 2 \\ \text { 西村伸也 }-* 3 & \text { 森下 満 }-* 4 \\ \text { 池上重康 }-* 4 & \text { 岡本浩—— }-* 5\end{array}$

キーワード :

中国東北部，ハルビン市，農村住宅，北方系居住文化，冬の暮らし

Keywords :

Northeast of China, Harubin city, Farm village, Northern dwelling culture,

Winter life

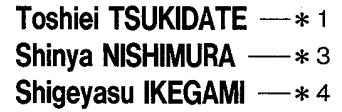

Toshiei TSUKIDATE - *1

Shinya NISHIMURA - *3

Shigeyasu IKEGAMI $-* 4$

In northern area, people developed the winter life style and dwelling culture to adapt to the cold and snowy environment. Therefore, we investigated the traditional dwelling culture and winter life style of farm villages near Harubin city, China.

According to this investigation, "KAN" which is the traditional heating system of farm house and underground storage of vegetable are the symbiosis to the environment. But, usually well and toilet are outside and not so good adaptation.

\section{1.はじめに}

\section{1-1 研究の背景と目的}

中国東北地区は、日本の北陸・東北・北海道とほぼ同緯度にある 大陸性気候の地域である。特に内陸部は冬の平均気温がー $20{ }^{\circ} \mathrm{C}$ に もなる極寒地である。この地域には満族をはじめに漢族、朝鮮族や オロッコ族など北方系少数民族が居住し、多様な北方系居住文化を 作り上げてきた。また、歴史的にも沿海州貿易などを通じて、日本 の北方地域との交流もあった地域である。これまであまり調查研究 が行われてこなかった北方系居住文化の特長を明らかにすると共に 日本の北方系居住文化と比較検証することを目指している。

本稿では、北方系居住文化を明らかにする一環として中国東北地 区ハルビン市近郊農村を対象に行った集落・住居及び冬の生活文化 に関する調查結果の概要を報告する。

\section{1-2 研究対使用地域と調查概況}

中国東北部は積雪寒冷な大陸性気候の地域である。今回報告する 黒竜江省の省都ハルビン市の近郊地域には広大な東北平野の中央に 当たる東経 126 度、北緯 46 度に位置する。大陸性気候のために夏 冬の寒暖の差は最暖月 $\left(7\right.$ 月) 平均気温 $21.7{ }^{\circ} \mathrm{C}$ 、最寒月 $(1$ 月) -20.1 ${ }^{\circ} \mathrm{C}$ 、年較差 $41.8{ }^{\circ} \mathrm{C}$ ときわめて大きい。しかし、降雪量は $46 \mathrm{~cm}$ と日 本の北国と較べるときわめて少ない。東北平野部は広大な畑作地帯 で、春小麦・トウモロコシ・コウリャン・煙草などの産地である。 2001 年 6 月にハルビン市郊外農村の予備調查を行い、8 月 3 10 日にかけてハルビン市近郊農村の紅星村・白石村 2 集落の本調 查を行った。さらに、冬の生活調查を 1 月中旬に行う予定であった が、地吹雪のために通行不能のために白石村手前の集落で農家 2 軒

\footnotetext{
*1 八戸工業大学建築工学科 教授・工博 (干031-8501 八戸市大字妙字大開88-1)

*2 北海道大学大学院工学研究科 助教授.工博

*3 新潟大学工学部 教授・工博

*4 北海道大学大学院 助手

*5 北海道大学大学院 博士課程
}

の冬の生活調査を行った。なお、本調査は北海道大学・新潟大学・ 八戸工業大学とハルビン工業大学・大連理工大学・北京清華大学の 北方系居住文化に関する共同研究として実施したものである。

今回は報告する主な内容は、北方系居住文化に関する調查結果の 一端として、集落および住居の空間構成の特徴および北方系居住文

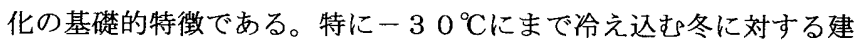
築的生活的工夫の概要を報告する。

\begin{tabular}{|c|c|c|c|}
\hline & 位 置 & $126^{\circ} \mathrm{E} \mathrm{46} \mathrm{N}$ \\
\hline 気 候 & 大陸性気候 \\
\hline 7 月平均気温 & $21.7^{\circ} \mathrm{C}$ \\
\hline 1 月平均気温 & $-20.1^{\circ} \mathrm{C}$ \\
\hline 降雪量 & $46 \mathrm{~cm}$ \\
\hline 主産業 & 烟作・牧音 \\
\hline
\end{tabular}

図-1 調查刘象集落の位置と特徵

表一 1 調查刘象集落の概要

\begin{tabular}{|c|c|c|}
\hline & 紅星村 & 白石村 \\
\hline 集落位置 & $\begin{array}{c}\text { 寶県（ハルビン市の東 } \\
\text { 方約 } 80 \mathrm{~km} \text { ) }\end{array}$ & $\begin{array}{c}\text { 阿城市 (ハルビン市の南 } \\
\text { 東約 } 70 \mathrm{~km} \text { ) }\end{array}$ \\
\hline 地 形 & 山裾・南向き緩斜面 & なだらかな起伏の平原 \\
\hline 戸 数 & 約50世帯 & 約80世帯 \\
\hline 形態・規模 & $\begin{array}{c}\text { 直角三角形 } \\
\text { 約 } 240 \mathrm{~m} \text { ×約 } 280 \mathrm{~m}\end{array}$ & $\begin{array}{c}\text { 長方形 } \\
\text { 約380m } \times \text { 約 } 200 \mathrm{~m}\end{array}$ \\
\hline 生 業 & $\begin{array}{c}\text { 畑作・牧畜 } \\
\text { (トウモロコシ・放牧) }\end{array}$ & $\begin{array}{c}\text { 畑作 } \\
\text { (トウモロコジ・タバコ) }\end{array}$ \\
\hline その他 & 近くに紅星湖と牧場 & 共同の煙草乾燥小屋 \\
\hline
\end{tabular}

*1 Prof., Dept. of Architectural Eng., Hachinohe Institute of Technology, Dr. Eng.

*2 Assoc. Prof., Faculty of Eng., Hokkaido University, Dr. Eng.

*3 Prof., Dept. of Architecture, Niigata University, Dr. Eng.

*4 Assistant, Faculty of Eng., Hokkaido University

*5 Graduate School of Eng., Hokkaido University 
P.

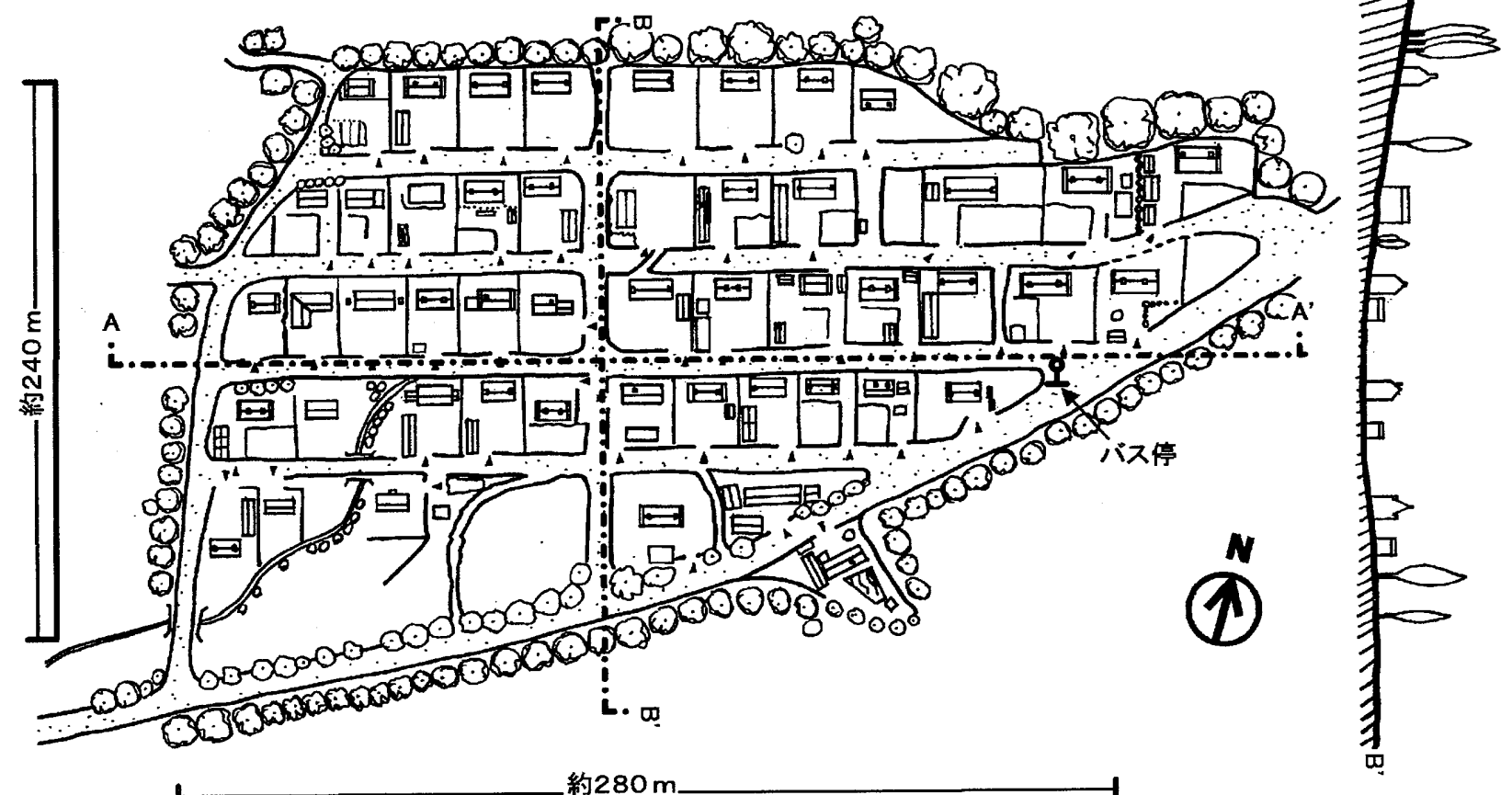

図一2 紅星村集落図（ハルビン市南東約 $70 \mathrm{~km}$ )

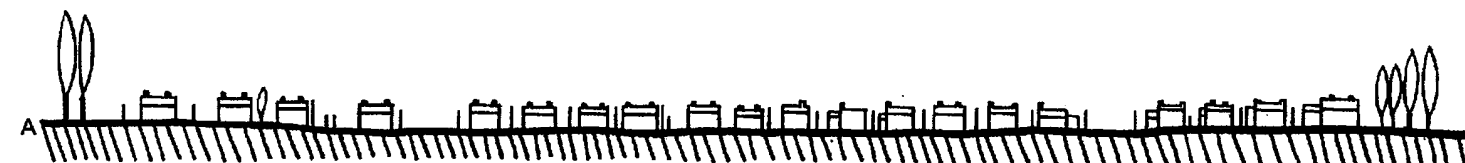
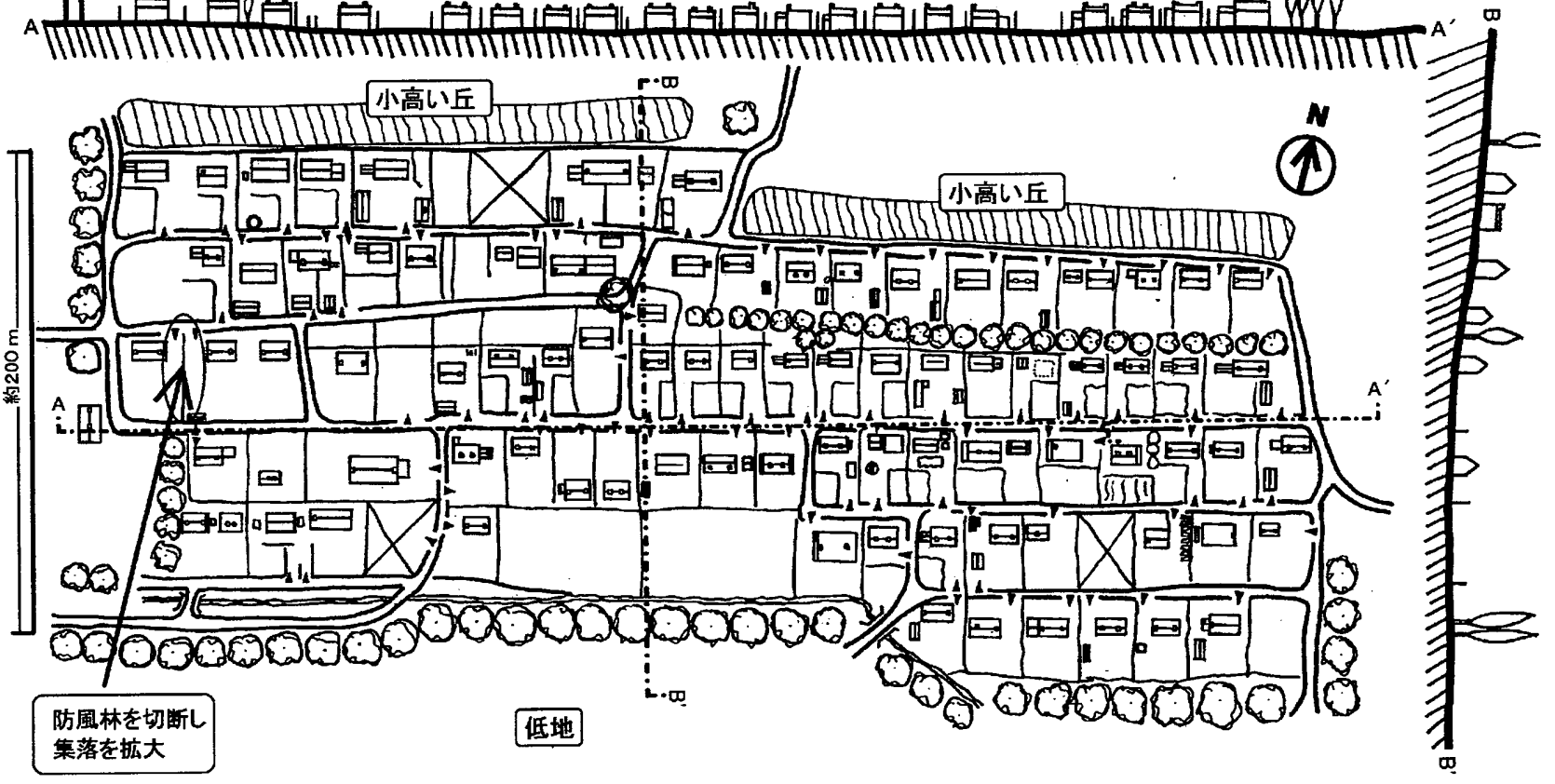

約 $380 \mathrm{~m}$

図一3 白石村集落図 (ハルビン市東約80キロ) 


\section{2. 集落および住居の概要}

2-1 紅星村（図一2、ハルビン市の南東に約 $70 \mathrm{~km}$ に位置）

ハルビン市の南東約 $70 \mathrm{~km}$ に位置する阿城市郊外の山間部にある 紅星湖周辺は観光地になっている。その奥の緩やかな山間部に位置 する49世帯の小集落が紅星村である。

紅星村はほぼ直角三角形をしており、集落の南東側に幹線道路が ある。集落のほぼ中央を南東側から南西側に小さな川が流れ、紅星 湖に注いでいる。地形を見ると、小川に沿った部分がやや低くなり、 道路沿いが少し高く、集落全体としては南から南西側、北側から北 東側にかけて緩やかな上り斜面になっている。集落内および集落周 辺には樹木が多く、防風林の役目も果たしている。

幹線道路が集落に対して斜めに通っているが、集落の中央部はほ ぼ長方形をしており、道路はほぼ直行している。各敷地はほぼ南南 東向きで間口約 $20 \mathrm{~m} \times$ 奥行約 $20 \mathrm{~m}$ 、約 $400 \mathrm{~m}^{2}$ 程度の広さである である。道路境に小さな堰があり、門・出入り口には踏み板が渡さ れている。道路境は柴を編んだ高さ $1.5 \mathrm{~m}$ 程度の垣根となっている ことが多く、屋敷境は土塀あるいは煉瓦塀の場合が多い。敷地の出 入口には幅 $2 \mathrm{~m}$ あまの門が右勝手に構えられ、屋敷内の通路は畑 と柴垣で分離されている。主屋は土壁に草苟あるいは瓦莫が一般的 で、最近は煉瓦造が増えている。住居の外観を特徴づけている暖房 用煙突は、主屋と分離、主屋妻壁側、主屋中央部の 3 パターンがあ る。煙突のパターンはカン・ペチカ・ストーブなどの暖房設備に対 忘している。主屋後ろには薪置場や物置小屋があり、少し離れて井 戸や便所があることが多い。特徵的な施設として高床式の穀物倉庫 ーボーミジャーズーがある。
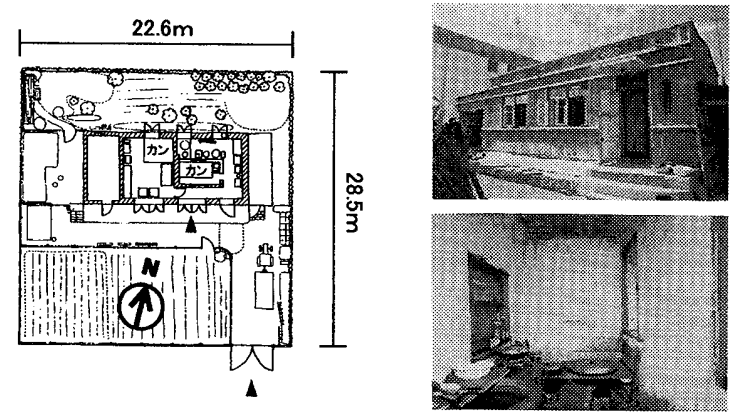

図-2 巍邸
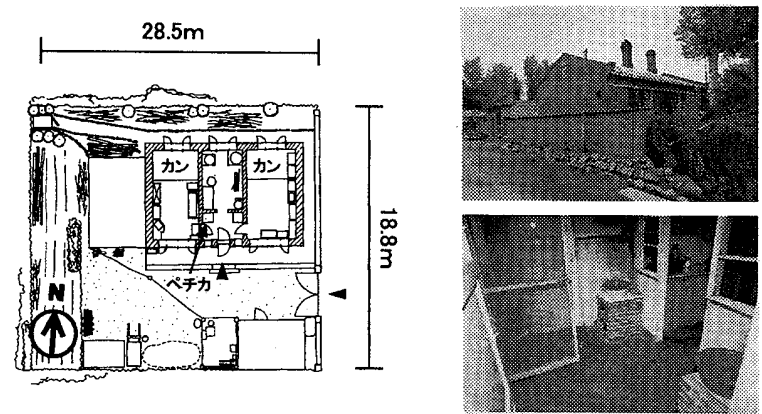

図-3 陳邸

2-2 白石村（図ー3、ハルビン市の東に約 $80 \mathrm{~km}$ の位置）

ハルビン市から東に約 $80 \mathrm{~km}$ にる寶県北側の松花江沿いにある 約 80 世帯の集落が白石村である。東北平野の大平原のなだらかな 起伏が続く中の僅かに南側一傾斜した平原端部にある集落である。
集落は東西約 $380 \mathrm{~m} \times$ 南北約 $200 \mathrm{~m}$ の長方形をしている。集落 へは南西側からアクセスする道路がつき、南側から集落へ入る。集 落内にはまとまった広場はないが、南入りの道路と集落道路が交差 する部分が少し広くなり角に店舗があることから、この辻が広場的 役割を果たしている。広場的な機能を兼ねている道路までがほほ平 坦であるが、その北側は少し小高い緩やかな斜面になっている。そ して、集落の南側の防風林・道路に沿って小川が流れている。

大平原にあるため集落はトウモロコシ烟と煙草畑に囲まれてい る。また、集落の要所には防風林と思われる樹木が南 ・西 ・ 北側に 残されている。しかし、西側や北側の防風林を切断して屋敷を増や しているが伺われる。

各屋敷はほぼ南向きに構えられ、道路は南あるいは北側にある。 門・出入り口は道路位置に従って、南入あるいは北入であるが、門 の位置は右勝手・左勝手が混在している。

屋敷は間口約 $20 \mathrm{~m} \times$ 奥行約 $25 \mathrm{~m}$ 、広さ約 $500 \mathrm{~m}^{2}$ 程度が一般的 である。門扉は鉄製が木製の約 2 倍に上り、道路境は萩などの生垣 が主である。主屋は土壁に草屋根あるいは瓦䓬が主であり、煙突は 主屋と分離、主屋妻壁側、主屋中央部の 3 パターンが見られる。外 便所に外井戸が一般的であるが、高床の觳物倉庫は見られない。
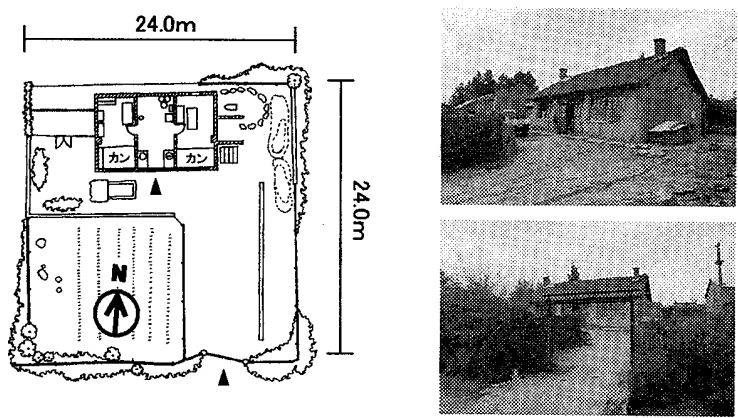

図-4 孫邸
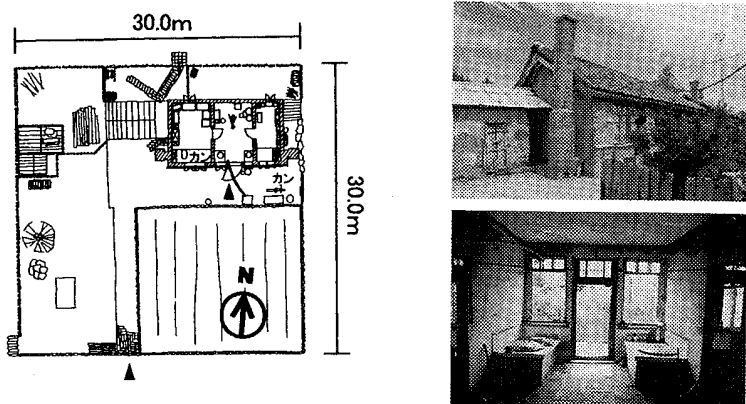

図一5 殷邸

\section{2-3 紅星村および白石村の集落及び住居の特徵（表一2）}

ハルビン市近郊の 2 集落を調査した結果、山裾農村と平原農村の は集落としての構えは、集村、東西方向の長軸、南向きの構えであ るなどほぼ同じである。しかし、白石村の敷地がやや広いものの、 道路・敷地形状などは同じであるが、各戸の屋敷構えに大きな差異 が見られた。

紅星村の屋敷は南北両側に道路があるが、右勝手の南入りが原則 である。一方、白石村は南北道路の場合でも南入りと北入の屋敷が 混在し、右勝手・左勝手も法則性が見られない。また、山裙の紅星 村では木製門扉・木柶や柴を編んだ柵が多いが、平原の白石村では 鉄製門扉に生垣が主である。白石村に生垣が多のは、大平原のため 
に木が貴重であることを示していよう。

極めて寒冷な地域であるが、両村ともに聞き取りでは雪囲いなど の仮設の防寒防雪対策は行われていなかった。気候防護対策を強い てあげれば、平原集落である白石村の西側に防風雪林があり、主屋 北側に柴を積んで風除けとしている点であろう。

\section{表一2２集落の屋教構えの比較}

\begin{tabular}{|c|c|c|}
\hline & 紅 星 村 & 白 石 村 \\
\hline 地 形 & 山裙 & 平原端部 \\
\hline 菓落形態 & 集村 (三角形、長軸東西) & 集村（長方形、長軸東西） \\
\hline 數地形状 & 長方形（長軸：南北） & 長方形（長軸：南北） \\
\hline 數地面積 & 東西約 $20 m \times$ 南北約 $20 m$ & 東西約 $20 m \times$ 南北約 $25 \mathrm{~m}$ \\
\hline 數地出入口 & 南側中心 $(88 \%)$ & 南側および北側 \\
\hline $\begin{array}{ll}\text { 門霏 } \\
\end{array}$ & 木彆主体 (65\%) & 鉄製主体 (71\%) \\
\hline 城・垣 & 木栅主体 (65\%) & 生垣主体（65\%） \\
\hline 屋數構え & 右勝手中心 & 五勝手・左勝手が混在 \\
\hline 雪対策 & 特になし & 防風雪林 \\
\hline 備 考 & 特になし & 煙草乾燥小屋 \\
\hline
\end{tabular}

3. ハルビン市近郊農村における冬の暮らしの工夫

\section{3-1 暖房設備}

伝統的な主屋の間取りは 3 室に分かれているが、主な暖房設備は 中央の堂屋に出入口の両側にある<杭 >である。堂屋両側の部屋の 南側には南側の空に接して部屋幅一杯の幅約 $2.5 \mathrm{~m}$ 、奥行約 $1.8 \mathrm{~m}$ 、 高さ約 $65 \mathrm{~cm}$ の炕があり、部屋の位置により東炕および西炕と呼ば れている。炕の然料は、中国東北地区が石炭の大産地であることか ら主に石炭であり、付属屋に石炭庫がある。また、炕だけでは寒い のでペチカを併用している農家もみられ、最近では石炭ストーブも 增えている。暖房設備の違いは煙笑に現れている。古い炕の場合は 煙突が主屋から独立し、普通の炕の場合は妻壁の両側に煙突がある。 ペチカを併用している場合は、切り妻屋根の中央部に煙突がつく。

\section{3-2 野菜の地下貯藏室}

中国でも都市部では商業施設が充実し、冬でも生鮮食料を購入で きるようになってきたが、農村部では未だ冬の食料の保存が重要で ある。野菜を保存する地下貯藏室には 3 パターンがみられる。一つ は屋外の高さ約 $2.5 \mathrm{~m}$ 、直径約 $3 \mathrm{~m}$ のドーム状の大きな貯藏室であ る。地下貯蔵室の出入口には霜が付いているが、野菜を貯蔵する当
たりは+ $3^{\circ} \mathrm{C}$ 前後である。他の 2 例は主屋内であるが、一つは堂屋 の奥、もう一つは西炕の奥にある場合である。主にジャガイモ・白 菜などが保存されている。

3ー3 穀物保存用高倉（ボーミジャーズ）

山間の集落と平原の集落では農業形態が異なるが、両集落ともに トウモロコシなどの款物保存用高倉（ボーミジャーズ）がある。山 間の紅星村の高倉は主屋のそばあるいは屋敷内通路脇にあり、簡易 ではあるが校倉造状で、床高も約 $100 \mathrm{~cm}$ 程度と高い。一方、白石 村では屋敷内の畑に単にトウモロコシを収納するだけの非常に簡素 な床高約 50 センチ程度の高倉である。高倉の位置と床高の差異は 雪によるものと推定される。

3ー4 井戸・トイレ

- $30{ }^{\circ} \mathrm{C}$ にも冷え込む極寒の地であるが、外井戸の場合が多い。 内井戸は、堂屋の奥にあることが多く、内井戸であることを自慢げ に説明してくれた。

また、トイレは外便所が一般的で、主屋の南西側の畑の道路側隅、 あるいは主屋の裏側の敷地境にあることが多い。

\section{4. まとめ}

(1)調查した 2 集落は規則的な敷地割・屋敷構えを持つ計画村とであ る。山間集落と平地集落では門扉・屏・出入口の位置に違いがあり、 平地集落では南北にある屋敷の出入口が特徴である。

(2)草莫屋根に土壁造の古い家でも建築後 50 ～ 60 年程度である。 間取は一房三室型であるが、最近は四室型や卧室分割型も見られる。 (3)主な冬への備えは、〈カン>、〈ぺチカ>、〈ムロ〉であり、雪 囲い等はなかった。外便所、外井戸が多く、暖房設備を除けば、日 本の伝統的北国農村と類似性が見られた。

\section{謝辞}

本研究を谁めるに当たって、烸広天教授・周立軍副教授（ハルビ ン工業大学)、陸教授（大連理工大学）、周教授（清華大学）のご 協力を得たことを末尾ながら記し、謝意を表します。 参考文献

1. 伊東恒治 : 北支蒙腲の住居、弘文堂、昭和 18 年

2. 張馼萲：吉林民居、中国建築工業出版社、1985年
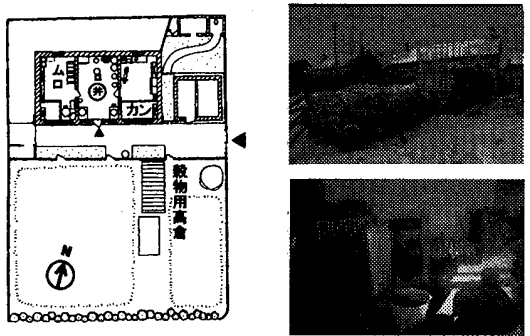

図-6 高倉・内井戸（王邸、賓県）
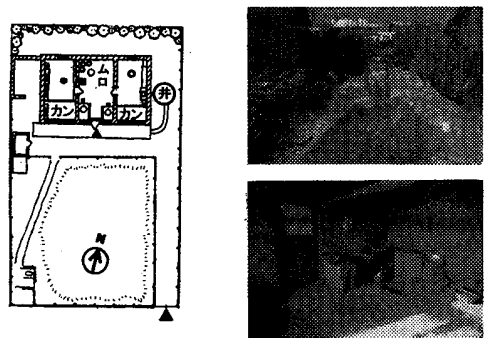

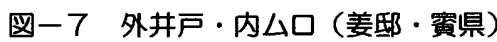

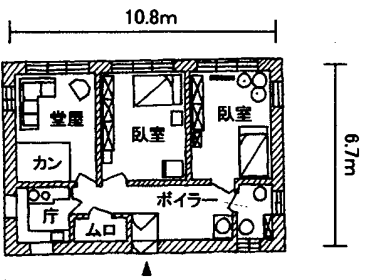

図-8 款邸（ハルビン市郊外）

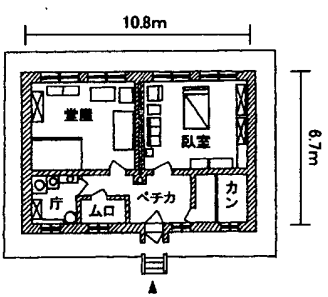

図一9 王邸（ハルビン市郊外）
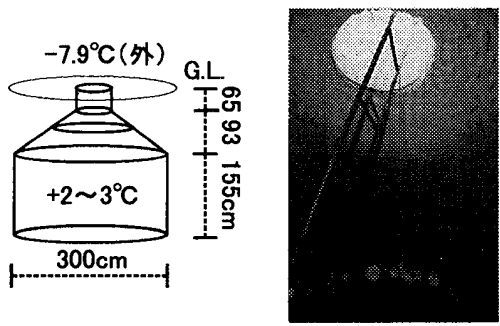

図一10 棟瓦造による外 $\Delta$ 口(銐邸・賏県)
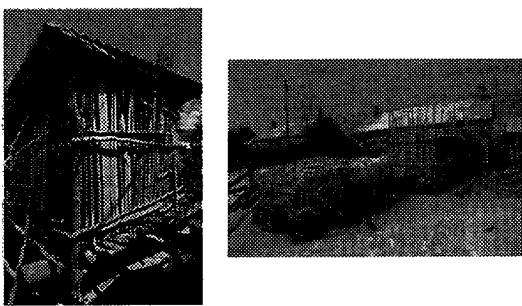

図-11 山間部 (左) と平原 (右) の高倉 [2002年 4 月19日原稿受理 2002年 7 月23日採用決定］ 